\title{
Some Physiological Aspects and Production Trends of Certain Coconut Hybrids and Their Parents
}

\author{
T. S. RAVEENDRAN*, H. VIJAYARAGHAVEN \\ and \\ T. K. RAMACHANDRAN
}

Coconut Research Station, Veppankulam 614906

Tamil Nadu, India.

\begin{abstract}
Attempts were made to study the physiological basis for the variation in production trends of certain coconut hybrids and their parents. The hybrids in general recorded more chlorophyll content, photosynthetic rate, soluble protein and nitrate reductase activity and low respiratory rates. East Coast Tall amongst the parents and Malaysian Dwarf Yellow (MDY) X East Coast Tall (ECT) and its reciprocal amongst the hybrids were identified as better material for the production potential in terms of high photosynthetic rates coupled with low respiratory rates. The studies indicate the possibility of using these physiological parameters in selecting vigorous seedlings in the nursery stage itself.
\end{abstract}

\section{INTRODUCTION}

Ever since the hybrid vigour in coconut was observed in 1932, its increased potential is being exploited by the production of hybrids involving typica (tall) and nana (dwarf) varieties. Patel (1937) observed that the maximum vigour in coconut was obtained when typica was used as the female parent and nana as the male parent. High degree of allogamy does not permit the prodution of genetically pure talls by inbreeding. Hence in the nursery, the hybrid seedlings are required to be subjected to vigorous selection methods so as to avoid palms with poor combination of genes. Physiological and biochemical characteristics such as enzyme activity, chlorophyll content, photosynthetic rate, leaf area and dry matter production may prove dependable characters and can be exploited to screen progenies in the nursery. Not much work has been done in this respect in coconut. Shivashankar et al. (1982) obtained a high positive correlation between nitrate reductase activity and annual nut yield in coconut. This paper describes the results of a study undertaken at the Coconut Research Station, Veppankulam, Tamil Nadu, India, to relate several physiological attributes to floral and production characters in 15 - year old coconut palms.

\section{MATERIALS AND METHODS}

The study was undertaken using four parental genotypes comprising one typica variety, East Coast Tall (ECT) and three nana varieties, Malaysian Dwarf Yellow (MDY), Malaysian Dwarf Green (MDG) and Ayiramkachi (AY) and their three direct $(T \times D)$ and three reciprocal $(D \times T)$ hybrids.

\footnotetext{
* Present Address: Agricultural Research Station, Aliyarnagar 642 101, Tamil Nadu, India.
} 
The youngest unfolded leaf in the crown was sampled for apparent photosynthesis (Mathew and Ramadasan, 1974). The leaf No. 14, counted from the youngest unfolded leaf as No. 1, was used to study the chlorophyll content and nitrate reductase activity (Mathew and Ramadasan, 1973; Shivasankar and Ramadasan, 1983). The photosynthetic and respiratory rates were estimated by using differential Infra Red Gas Analyser (ADC 225/2K England). Chlorophyll ' $a$ ' and ' $b$ ' were determined spectrophotometrically using the method of Mackinney (1941). The soluble protein (Lowry et al., 1951) and nitrate reductase activity (Hageman and Huchlesby, 1971) were also determined in the leaf samples. These physiological observations and biochemical analyses were carried out during 1986.

In 1987 and 1988, data on height, girth, number of functional leaves, number of leaf scars in one metre length and total bunches were recorded. In each tree, the number of spikelets (branches) per spadix, length of spikelet, percentage of spikelets with button nuts and total button nuts produced were recorded. The yield in terms of number of nuts and weight of fully matured nuts was recorded. The number of barren nuts was counted and the percentage of barren nuts and setting (nuts produced to total button nuts) were also estimated. All the observations were recorded at quarterly intervals, except barren nut counts, button nuts and nut yield, which were recorded monthly. The number of palms subjected to the study including the physiological parameters was ten in each of ECT $x$ MDY, ECT $x$ MDG, ECT $x$ $A Y$ and MDY $\times$ ECT, eight in ECT, four each in MDG $\times$ ECT and AY $\times$ ECT, three in MDG and two each in MDY and AY.

\section{RESULTS AND DISCUSSION}

The data on physiological parameters are presented in Table 1. In general, parents and hybrids were more or less similar in their photosynthetic rates, nitrate reductase activity and soluble protein content. The content of chlorophyll ' $a$ ' and ' $b$ ' was higher in hybrids than in the parents. In two high yielding coconut hybrids, D x $\mathrm{T}$ and $\mathrm{T} \times \mathrm{D}$, Mathew and Ramadasan (1973) observed a higher chlorophyll content, compared with that in West Coast Tall variety. The chlorophyll a/b ratio was higher in parents than in hybrids.

In the parental types, the highest photosynthetic rate was observed in ECT. In the hybrids, this parameter was highest in MDY $x$ ECT, followed by its reciprocal cross. Thus the hybrids involving MDY and ECT recorded higher photosynthetic rates than those involving other parental types.

In the parental types, the highest respiratory rate was recorded in AY, while in the hybrids this parameter was highest in AY x ECT. In general, a rather high energy loss due to respiration was observed in parental types, indicating a higher relative net energy assimilation of hybrids.

Shivashankar et al. (1982) reported a higher rate of photosynthesis in Chowghat Dwarf Orange (CDO) when compared to T x D. However, CDO recorded higher dark respiration thereby nullifying the advantage of high rate of photosynthesis. In our studies, ECT had the highest photosynthetic rate of $31.2 \mathrm{mg} \mathrm{CO} / \mathrm{dm}^{-2} / \mathrm{h}$ and lowest respiratory rate of $8.914 \mathrm{CO}_{2}$ assimilated / $20 \mathrm{mg}$ of dry leaf / $15 \mathrm{~min}$ of feeding. Among the six hybrid combinations, MDY $x$ ECT had the highest physiological efficiency followed by its reciprocal ECT $x$ MDY. The soluble protein content and nitrate reductase activity were also higher in ECT, MDY $\times$ ECT and ECT $x$ MDY. 
Table 1. Physiological parameters of parents and hybrids

\begin{tabular}{|c|c|c|c|c|c|c|c|}
\hline Variety & $\begin{array}{c}\text { Chloro- } \\
\text { phyll }(\mathrm{mg} / \mathrm{g}) \\
a\end{array}$ & $\begin{array}{l}\text { Content } \\
\qquad b\end{array}$ & $a / b$ ratio & $\begin{array}{c}\text { Photosynthetic } \\
\text { rate } \\
m g \mathrm{CO}_{2}^{d m-2}{ }_{\mathrm{h}}^{-1}\end{array}$ & $\begin{array}{l}\text { Respiratory } \\
\text { rate(1) }\end{array}$ & $\begin{array}{l}\text { NR Activity } \\
\text { (2) }\end{array}$ & $\begin{array}{l}\text { Soluble } \\
\text { Protein } \\
\text { (mg/g) }\end{array}$ \\
\hline \multicolumn{8}{|l|}{ PARENTS } \\
\hline \multicolumn{8}{|l|}{ Tall } \\
\hline 1. ECT & 0.74 & 0.33 & 2.24 & 31.2 & 8.9 & 10.5 & 13.2 \\
\hline \multicolumn{8}{|l|}{ Dwarf } \\
\hline 1. MDY & 0.61 & 0.29 & 2.10 & 21.7 & 10.5 & 7.9 & 11.2 \\
\hline 2. AY & 0.63 & 0.30 & 2.10 & 24.2 & 11.6 & 6.6 & 7.4 \\
\hline 3. MDG & 0.75 & 0.34 & 2.21 & 24.1 & 9.4 & 7.2 & 9.2 \\
\hline \multicolumn{8}{|l|}{ HYBRIDS } \\
\hline \multicolumn{8}{|l|}{ Tall $x$ Dwarf } \\
\hline 1. ECT $x$ MDY & 0.77 & 0.36 & 2.14 & 28.9 & 9.4 & 9.3 & 12.6 \\
\hline 2. ECT $\times$ MDG & 0.65 & 0.34 & 1.91 & 24.8 & 7.5 & 8.8 & 12.1 \\
\hline 3. ECT $\times A Y$ & 0.68 & 0.33 & 2.06 & 22.8 & 9.0 & 6.9 & 7.8 \\
\hline \multicolumn{8}{|l|}{ Dwarf $x$ Tall } \\
\hline 1. MDY $x E C T$ & 0.88 & 0.49 & 1.80 & 33.4 & 5.6 & 10.6 & 14.8 \\
\hline 2. MDG $\times \mathrm{ECT}$ & 0.71 & 0.39 & 1.82 & 23.4 & 9.4 & 7.6 & 9.9 \\
\hline 3. AY $x E C T$ & 0.69 & 0.33 & 2.09 & 19.2 & 12.9 & 6.4 & 6.6 \\
\hline
\end{tabular}

1. ${ }^{14} \mathrm{CO}_{2}$ assimilated $/ 20 \mathrm{mg}$ of dry leaf $/ 15$ min feeding

2. $\mu$ moles $\mathrm{NO}_{3}{ }^{-1}$ reduced/g fresh weight/h

A perusal of the vegetative data in Table 2 indicates that hybrids in general have a higher number of leaves and number of bunches per year which are the main components determining the yield. Patel (1938) reported that in an adult palm, the length of stem and number of leaves in the crown are significantly correlated with average yield. Satyabalan et al. (1972) also found a similar highly significant correlation between height, number of leaves in the crown and yield of nuts. MDY among the parents and MDY $\mathrm{x}$ ECT and ECT $\mathrm{x}$ MDY among the hybrids had higher number of leaves and bunches than other varieties. It could be inferred that both these components could have been imparted by MDY in the hybrid. The number of leaf scars $\mathrm{m}^{-1}$ in these two hybrids is also relatively less, indicating the low growth increment, similar to ECT.

The number of spikelets and the length of spikelet are higher in the hybrids (Table 3). The annual production of button nuts in ECT was less than that of the three dwarf parents. However, the hybrids were intermediate for the production of button nuts (Table 4). The highest yield realised in respect of hybrids therefore is a function of higher setting percentage and optimum number of button nuts as compared to low yield in parents, which is due to poor setting. Barrenness is also less in hybrids in the present study. The highest yield was recorded in ECT $x$ MDY. 
Physiological Aspects and Production Trends

Table 2. Vegetative growth and production in parents and hybrids

\begin{tabular}{lccccc}
\hline \multicolumn{1}{c}{ Variety } & $\begin{array}{c}\text { No. of functional } \\
\text { leaves }\end{array}$ & $\begin{array}{c}\text { Height of palm } \\
(\mathrm{m})\end{array}$ & $\begin{array}{c}\text { Girth at base } \\
(\mathrm{cm})\end{array}$ & $\begin{array}{c}\text { No. scars } \mathrm{m}^{-1} \\
(\mathrm{~m}) \cdot\end{array}$ & $\begin{array}{c}\text { No. of bunches } \\
\text { per year }\end{array}$ \\
\hline PARENTS & & & & \\
Tall & 25.0 & 10.6 & 87.5 & 26.0 & 11.0 \\
1. ECT & & & & & \\
Dwarf & 33.0 & 6.2 & 65.0 & 34.0 & 14.0 \\
1. MDY & 31.0 & 5.4 & 65.0 & 33.7 & 12.5 \\
2. AY & 24.7 & 4.6 & 66.7 & 32.0 & 7.7 \\
3. MDG & & & & & \\
HYBRIDS & & & & & \\
Tall x Dwarf & & & & & \\
1. ECT x MDY & 37.5 & 7.1 & 77.9 & 23.5 & 13.9 \\
2. ECT x MDG & 33.2 & 5.9 & 75.7 & 25.3 & 8.1 \\
3. ECT x AY & 28.3 & 5.5 & 72.4 & 26.3 & \\
& & & & & \\
Dwarf x Tall & & & & & \\
1. MDY x ECT & 37.8 & 6.8 & 72.9 & 24.0 & 14.4 \\
2. MDG x ECT & 30.3 & 3.4 & 67.5 & 32.0 & 11.0 \\
3. AY x ECT & 30.0 & 3.4 & 65.0 & 27.5 & 10.0 \\
\hline
\end{tabular}

Table 3. Floral characters of parents and hybrids

\begin{tabular}{lccccccc}
\hline Variety & $\begin{array}{c}\text { No. of } \\
\text { Palms } \\
\text { studied }\end{array}$ & $\begin{array}{c}\text { No. of } \\
\text { spikelets }\end{array}$ & $\begin{array}{c}\text { Length } \\
\text { of } \\
\text { spikelets } \\
\text { (cm) }\end{array}$ & $\begin{array}{c}\% \\
\text { spikelets } \\
\text { with but- } \\
\text { ton nuts }\end{array}$ & $\begin{array}{c}\text { \% spikelets with } \\
\text { one } \\
\text { button- } \\
\text { nut }\end{array}$ & $\begin{array}{c}\text { Toral momber } \\
\text { one but- } \\
\text { ton/nut }\end{array}$ & $\begin{array}{c}\text { of button } \\
\text { nuts/per } \\
\text { year }\end{array}$ \\
\hline PARENTS & & & & & & & \\
Tall & & & & & & & \\
1. ECT & 8 & 29.7 & 40.0 & 49.9 & 63.8 & 33.2 & 17.0 \\
Dwarf & & & & & & & \\
1. MDY & 2 & 31.7 & 32.5 & 66.5 & 42.0 & 58.0 & 23.0 \\
2. AY & 2 & 26.0 & 39.8 & 83.0 & 79.6 & 20.4 & 41.0 \\
3. MDG & 3 & 26.0 & 38.5 & 84.6 & 90.6 & 9.4 & 54.7 \\
HYBRIDS & & & & & & & \\
Tall $\times$ Dwarf & & & & & & & \\
1. ECT x MDY & 10 & 34.1 & 44.6 & 56.0 & 84.8 & 15.2 & 24.2 \\
2. ECT x MDG & 10 & 36.1 & 43.9 & 57.4 & 89.6 & 10.4 & 21.1 \\
3. ECT x AY & 10 & 28.5 & 39.8 & 49.9 & 78.6 & 21.4 & 22.8 \\
Dwarf $\times$ Tall & & & & & & & \\
1. MDY x ECT & 10 & 35.6 & 42.8 & 43.5 & 89.3 & 10.7 & 18.3 \\
2. MDG x ECT & 4 & 35.3 & 43.8 & 66.8 & 79.8 & 20.2 & 31.7 \\
3. AY x ECT & 4 & 32.0 & 36.8 & 82.2 & 79.5 & 20.5 & 55.8 \\
\hline
\end{tabular}


Table 4. Production in parents and hybrids

\begin{tabular}{|c|c|c|c|c|c|}
\hline Variety & $\begin{array}{l}\text { Total button nuts } \\
\text { produced/year }\end{array}$ & $\begin{array}{l}\text { Nut yield } \\
\text { palm/year }\end{array}$ & $\begin{array}{c}\text { Button nuts: nuts } \\
\text { ratio }\end{array}$ & $\begin{array}{l}\text { Barren nuts as } \\
\% \text { of total nuts }\end{array}$ & $\begin{array}{c}\text { Total weight of } \\
\text { nuts }(\mathrm{kg})\end{array}$ \\
\hline \multicolumn{6}{|l|}{ PARENTS } \\
\hline \multicolumn{6}{|l|}{ Tall } \\
\hline 1. ECT & 243 & 67.7 & 27.9 & 4.08 & 69.7 \\
\hline \multicolumn{6}{|l|}{ Dwarf } \\
\hline 1. MDY & 291 & 59.7 & 20.5 & 4.89 & 37.0 \\
\hline 2. $\mathrm{AY}$ & 359 & 46.3 & 9.6 & 18.50 & 27.3 \\
\hline 3. MDG & 389 & 37.3 & 12.9 & 46.20 & 18.0 \\
\hline \multicolumn{6}{|l|}{ HYBRIDS } \\
\hline \multicolumn{6}{|l|}{ Tall $x$ Dwarf } \\
\hline 1. ECT $\times$ MDY & 279 & 95.0 & 34.0 & 4.22 & 92.4 \\
\hline 2. ECT $\times \mathrm{MDG}$ & 278 & 88.8 & 31.9 & 2.62 & 81.4 \\
\hline 3. $\mathrm{ECT} \times \mathrm{AY}$ & 260 & 85.3 & 32.8 & 4.40 & 27.0 \\
\hline \multicolumn{6}{|l|}{ Dwarf $x$ Tall } \\
\hline 1. MDY $x$ ECT & 294 & 88.2 & 30.0 & 4.41 & 84.8 \\
\hline 2. MDG $\times \mathrm{ECT}$ & 274 & 75.9 & 27.7 & 2.41 & 74.8 \\
\hline 3. AY $x$ ECT & 325 & 55.0 & 16.9 & 12.50 & 41.6 \\
\hline
\end{tabular}

The physiological parameters can be related to the productivity components in hybrids and parents. ECT is the most efficient parent in the present study. The hybrids, which are physiologically more efficient than the parents, use the energy to produce a higher number of leaves, spadices and button nuts which are the most important yield components in coconut. However, in ECT, the energy translocation was more towards the structural part namely, the trunk. Thus a higher yield in hybrids could be associated with the higher photosynthetic rate, chlorophyll content and the lower respiratory ratio. Mathew and Ramadasan (1975) reported that an increase in chlorophyll content was seen to be associated with increased annual yield. These studies also indicate the possibility of using the physiological parameters for identifying superior seedlings in the nursery stage itself.

\section{ACKNOWLEDGEMENTS}

The authors are grateful to the Indian Council of Agricultural Research for financial help. The authors are thankful to Dr S Chelliah, Director, Tamilnadu Rice Research Institute, Aduthurai, for encouragement given in the course of the study.

\section{REFERENCES}

Hageman, R. H. and Huchlesby, D. P. (1971) Nitrate reductase from higher plants. In methods in enzymology 23; Part A (ed. Sanpietro, A) Academic press. New York. pp. 491 - 503.

Lowry, O. H., Rosebrough, Farr A. L. and Randall R. J., (1951) Protein measurement with the Folin- phenol reagent. J. Biol. Chem. 193: $265-278$ 
Mackinney, G. (1941) Absorption of light by chlorophyll Solutions. J. Biol. Chem. 140: $315-322$

Mathew, C. and Ramadasan A. (1973) Chlorophyll content in certain cultivars and hybrids of coconuts. J. Plant. Crops 1:96-98

Mathew, C. and Ramadasan A. (1974) Studies on photosynthesis in coconut palm; rate of apparent photosynthesis. Indian J. Exp. Biol. 12: 589 - 591

Mathew, C. and Ramadasan A. (1975) Photosynthetic efficiency in relating to annual yield and chlorophyll content in the coconut palm. J. Plant. crops 3: $26-28$

Patel, J. S. (1937) Coconut breeding. Proc. Assoc. Ecoon. Biol. 5: 25

Patel J. S. (1938) The coconut palm - A monograph. Government Press. Madras pp. $60-85$.

Shivashankar, S., Kasturi Bai, K. V. and Ramadasan, A. (1982) Comparative study of coconut genotypes for components of photosynthesis and respiration. Proc. Fifth Annual Symposium on plantation crops. CPCRI, Kasaragod, pp. 231-234.

Shivasankar, S. and Ramadasan A. (1983) Nitrate Reductase activity in coconut leaves. J. Sci. Food and Agri. 34: 1179-1184

Satyabalan, K., Mathew, J. and Radhakrishnan, V. (1972) Yield variation and its relationship with age and growth of under-planted coconut palms. Oleagineux 27 : 257-259. 